\title{
Dicrocoeliosis - the Present State of Knowledge with Respect to Wildlife Species
}

\author{
L. DUCHÁČEK, J. LAMKA
}

Department Pharmacology and Toxicology, Faculty of Pharmacy in Hradec Králové, Charles University in Prague, Czech Republic

Received April 16, 2003

Accepted September 22, 2003

\section{Abstract}

Ducháček L., J. Lamka: Dicrocoeliosis - the Present State of Knowledge with Respect to Wildlife Species. Acta Vet. Brno 2003, 72: 613-626.

The present paper summarizes contemporary knowledge concerning dicrocoeliosis (chronic disease of the liver caused by the lancet fluke Dicrocoelium dendriticum) as to its spraed, etiology, life cycle, epidemiology, pathogenesis, immunogenesis, clinical symptoms, diagnostics, therapy, prevention of dicrocoeliosis, and human infection. The major part of published data is connected with farm animal husbandry, dicrocoeliosis of wildlife species is examined to a limited extent only. Although dicrocoeliosis is intensively studied, numerous aspects of this trematodosis have to be verified. Control of dicrocoeliosis in domesticated and wildlife species is not fully effective at present.

Dicrocoelium dendriticum, lancet fluke

Dicrocoeliosis is a helmithosis caused by the lancet fluke Dicrocoelium dendriticum Rudolphi, 1819 (D. dendriticum, syn. D. lanceolatum, Dicrocoelidae, Platyhelminthes), parasitizing in the liver of ruminants as well as many other animals species including man. This parasitosis belongs to the six principal and economically most important pasture helminthoses of sheep and cattle-trichostrongylidosis, dictyocaulosis, protostrongylidosis, moniesiosis, fasciolosis, and dicrocoeliosis (Hiepe 1994). Parasitosis accompanies man and farm animals breeding from time immemorial. The eggs of $D$. dendriticum were found in the coprolites and paleofaeces of the prehistoric human population in Central Europe. Nevertheless, it is not certain whether the lancet fluke $D$. dendriticum was a real parasite, or whether the found eggs indicate pseudoparasitism after consummation of animal liver (Aspöck et al. 1999).

Spread of dicrocoeliosis

Dicrocoeliosis occurs in both pasture-bred and wildlife species throughout the world. The disease is common in those regions of Europe, Asia, North Africa and America, where the local conditions are favourable for certain species of earth snails and ants as intermediate hosts. Such regions in Europe are, e.g., mountain pastures of Alpine, Scandinavian and Mediterranean countries (Eckert and Hertzberg 1994); in Bohemia and Moravia (Czech Republic) dicrocoeliosis occurs in the regions with pasture breeding of ruminants, but its prevalence does not exceed 1\% (Jurášek and Dubinský 1993). It occurs in central and southern Bohemia as well as southern Moravia (Kotrlá et al. 1984). Lietava (1984) evaluated the prevalence of dicrocoeliosis in the region of Central Slovakia, which amounted to $54.8 \%$. Extensity of dicrocoeliosis in the northern part of central and eastern Slovakia ranged from $8 \%$ to $54 \%$ (Filo et al. 1986). In Hungary dicrocoeliosis ranks among the most frequently occurring parasitoses with the prevalence of $21 \%$ (Kas sai and Bekesi 1993). In Germany in the region of Frankfurt/Oder Stuhrberg et al. (1975) report the

Address for correspondence:

MVDr. Lubomír Ducháček

Faculty of Pharmacy, Charles University in Prague

Heyrovského 1203, 50005 Hradec Králové,

Czech Republic
Phone: +420495067353

E-mail: 420495514373

http://www.vfu.cz/acta-vet/actavet.htm 
prevalence of $31.5 \%$ in sheep. In the same region Schuster et al. (1991) describe the intensity of ovine infection within a range of 394-1849 trematodes. The endoparasitic fauna in the region of Swabian Alb (Germany) was investigated by Rehbein et al. (1998) and they demonstrated infection with $D$. dendriticum in all animals examined. In Spain in the province of Leon, Manga-González et al. (1991) report the prevalence of $63.6 \%$ in sheep, Ferre et al. (1994) the prevalence of $26.7 \%$, and González-Lanza et al. (1993) in the same province the prevalence of $37.6 \%$ in cattle. The immunity rate of infestation in Switzerland is reported by König and Gottstein (1997) as $44.7 \%$ in sheep and $31.4 \%$ in cattle. Cringoli et al. (2002) found $53.1 \%$ of bovine and $67.5 \%$ of caprine farms positive in region of southern Apennines. Findings of flukes in goats were also described by Chartier and Reche (1992) in the southern part of the region of Poitou-Charentes in France. Gargili et al. (1999) found $23.5 \%$ prevalence in sheep and $2.6 \%$ prevalence in goats in Trakya (the European part of Turkey). The immunity rate of sheep and goats in Himachal Pradesh (India) was examined by Jithendran and Bhat (1996). Coprological studies in these migrating animals revealed $8.1 \%$ of positive sheep and $4.1 \%$ of infected goats. According to Kas sai (1999), dicrocoeliosis does not occur in Australia at present. Jurášek and Dubinský (1993), however report its occurrence as the result of introduction. Causative agent of dicrocoeliosis known from southern Africa is Dicrocoelium hospes, Looss, 1907 (Eckert et al. 1992).

In Europe the parasitosis occurs ubiquitarily in wildlife species (Kutzer 1997). It has been reported to occur in a population of moufflon in Spain (Lavin et al. 1998), Bulgaria (Nahlik et al. 1996), and there has been isolated findings in moufflon and fallow deer in Hungary (Andras 1995; Takacs 2000). Dicrocoeliosis has occasionally been found in chamois in Slovakia and in Japan (Ciberej et al. 1997; Nakamura et al. 1984), roe deer in Switzerland (Nesvadba 2000b), and in hare in Finland (Soveri and Valtonen 1983). In moufflon of the former Czechoslovakia Dyk and Chroust (1973) have reported the prevalence of dicrocoeliosis in two localities in the area of Blansko at the prevalences of $100 \%$ a $73.6 \%$. Lochman et al. (1979) report it occurrence virtually in all regions with moufflons in this country and in several localities with red deer, fallow deer, roe deer, and white-tailed deer, too. It has also been found in hare and wild rabbit (Páv et al. 1981). Chroust (2001) has reported the prevalence of dicrocoeliosis in moufflons in a range of $0-89 \%$, in chamois $0-11 \%$, and in roe deer $0-12 \%$.

Causative agent

The adult fluke is dorsoventrally flattened, of lanceolate shape, transparent, 5-15 mm long, and $1.5-3 \mathrm{~mm}$ wide. The parasite is localized in the biliary tract and the gall bladder, or in the outlet of the pancreas. The life cycle of lancet fluke lasts six and more months (Kas sai 1999). Kirkwood and Peirce (1971) obtained from two slaughtered sheep, which had been kept without a possibility of reinfection for six years, 365 and 189 adults. The eggs of these flukes were still viable.

The eggs of $D$. dendriticum are oval-shaped, dark brown, and very small (36-45 $\times 20-30$ $\mu \mathrm{m})$. They have a lid and contain a mature miracidium. They are highly resistant to the action of low or high temperatures and drying, they can winter and survive on the pastures for at least 10-12 months (Odening 1969). Alunda and Rojo-Vázquez (1984) examined the effect of some abiotic factors on the survival of the eggs of $D$. dendriticum under laboratory conditions. The highest mortality of eggs was observed at a relative density of $75-80 \%$ and at a temperature higher than $18^{\circ} \mathrm{C}$. The authors concluded their paper with a persuasion that the principal cause of the mortality of the eggs could be the action of some microorganisms. Alunda and Rojo-Vázquez (1983) carried out also studies of the survival and infectivity of the eggs of $D$. dendriticum in ground conditions. They assumed that mortality of the eggs 
was independent of their age, but that there was a marked effect of the season of the year. Studies of infectivity of the eggs of $D$. dendriticum by means of experimental infection of suitable intermediate hosts showed that there was no decrease in the infectivity of eggs in the course of the experiment (15 months).

\section{Spectrum of definitive hosts}

The definitive hosts are various species of mammals, in particular the sheep, goat, cattle, moufflon, red deer, fallow deer, white-tailed deer, roe deer, buffalo, camel, hare, rabbit, as well as the horse, pig, dog, rodents, and man (Kas sai 1999; Eckert et al. 1992; Lochman et al. 1979; Jíra 1998). Isolated findings have been reported in the donkey (Demir et al. 1995), yak (Ansari et al. 1989), chamois (Ciberej et al. 1997; Nakamura et al. 1984), and the cat (Nesvadba 2000a). D. dendriticum can exceptionally also parasitize in birds (Macko and Štefančíková 1996).

\section{Life cycle}

Two intermediate hosts are necessary for the development of the parasite (a triheteroxenous development). The first one is a terrestrial snail, which swallows eggs containing the miracidium in the fecal substrate. In experimental infection, $17.5-75 \%$ of snails were infected in this way (González-Lanza et al. 1997). More than 99 snail species were demonstrated to be intermediate hosts of $D$. dendriticum (Otranto and Traversa 2002). The asexual development, in the course of which the miracidium is transformed via sporocysts of the $1^{\text {st }}$ and $2^{\text {nd }}$ order into cercaria, takes 3-4 months (Kassai 1999). This period, however, fluctuates considerably in dependence on temperature (Eckert et al. 1992). When cercaria are completely mature they migrate from the hepato-pancreas to the pulmonary cavities with help of their tails, enzymatic products and stalets inside their oral suckers (Otranto and Traversa 2002). Cercaria are excreted by snails in mucous balls. They can be up to $2 \mathrm{~mm}$ in diameter and they contain up to 400 cercaria (Kotrlá et al. 1984). Otranto and Traversa (2002) document excretion of at least 5000 cercaria. Infected snails can winter and survive for a period of 2-3 years (Eckert et al. 1992). But according to Schuster (1992), the infection of snails with fluke interferes with their capability of reproduction and average life cycle. Schuster (1993) has also found that the majority of the snails Helicella obvia are infected in the autumn in the second year of their lives. The percentage of snails which contain daughter sporocysts is highest in spring. Expulsion of cercarial balls can be induced only in May and June. The viability of cercaria in this mucous aggregate lasts only for a few days (Eckert et al. 1992).

The second intermediate host is ant (Formica spp.) which swallows cercaria. They encyst in the body cavities of ants and within 1-2 months they develop into metacercaria. There can be even about 100 of them in one ant (Vrzgula and Jag oš 1986; Jurášek and Dubinský 1993). Schuster (1991) examined the factors influencing the intensity of the occurrence of metacercaria of $D$. dendriticum. He found a dependence of the intensity of infection on the length of ants, but not on the species of ants, or the period of their collection. Cercaria act on the nervous system (suboesophageal ganglion) of the intermediate host and make ants to remain on plant tops due to a cataleptic spasm, if the temperature is lower than $15^{\circ} \mathrm{C}$. The infected ants can thus be swallowed more easily by grazing definitive hosts (Kas sai 1999). Behavioural aspects in ants as supplementary intermediate hosts of $D$. dendriticum were evaluated by Spindler et al. (1986). These authors investigated which parts of plants are attractive for infected ants and found that flowers were evidently preferred to other parts of plants. When examining ants during day hours, they found that with increasing temperature ants leave plants (they appear mainly at lower temperatures in the morning and in the evening), nevertheless in the period when temperature was highest, a certain percentage of 
ants still remained clinging to plants. They also examined the distances between the anthill and the sites with clinging ants and found that the majority of infected ants were found in the vicinity of the anthill (3.65 $\mathrm{m}$ from the anthill), but some of them were found even within $14 \mathrm{~m}$ from the anthill.

Infection of the definitive host of parasitosis commences when ants containing metacercaria are swallowed. Badie (1978) noticed that an increased number of clinging ants occurred in the period of rainfall, whereas the minimum was at high temperatures of the culminating summer. When the infected ant is swallowed by the host, young dicrocoelia migrate via ductus choledochus into the biliary ducts, but there is no parenchymatous migration in the liver (Kassai 1999). Metacercaria excyst from the ants due to the action of duodenal enzymes (Otranto and Traversa 2002). Alzieu and Ducos de Lahitte (1991), Hillyer and Hopla (1982), and Lochman et al. (1979) also report possible migration via the portal blood system. The prepatent period lasts 7-9 weeks, the whole life cycle then approximately 6 months (Kassai 1999). As the miracidium produces numerous sporocysts of the first and second generation, which subsequently give rise to cercaria (1040 from one sporocysts), one egg can theoretically produce up to 400000 of adults (Kotrlá et al. 1984).

\section{Epidemiology}

The important factors limiting presence of dicrocoeliosis (Otranto and Traversa 2002) are mainly:

1. The environmental and ecological factors;

2. The presence and aetiology of intermediate hosts;

3. The presence of definitive hosts.

Dicrocoeliosis occurs in large lowland or mountain pasture areas, which provide suitable conditions for the survival and development of the individual species of terrestrial snails and ants (Eckert and Hertzberg 1994). Intermediate hosts do not require damp surroundings and they can therefore occur in pastureland diffusely. The disease occurs mainly in drier regions with limestone subsoil (Jurášek and Dubinský 1993). Stuhrberg et al. (1975), however, draws attention to the fact that in Germany dicrocoeliosis is not only limited to mountainous limestone regions, but it also occurs in lowlands with a small amount of limestone in the brown-soil area of Frankfurt/Oder. On the other hand, potential intermediate hosts are known to occur in mountain pastures in the altitudes of $1800-2600 \mathrm{~m}$ in various countries (e. g., in Austria, Switzerland, and Spain) (Gebauer and Hohorst 1968; Meier 1987; Manga 1992). Mountain pastures are contaminated with the eggs of fluke mainly from infected domestic ruminants, but wild ruminants, rabbits, and hares can also contribute to the spread of infection (B oray 1985). Chroust (2001) in this connection also draws attention to the importance of the wild boar. It is the wildlife species infected with flukes that disseminates the germs also in the pastures shared with farm animals, thus becoming a significant factor in the maintenance of the localities of the disease and overall spread of dicrocoeliosis (Jurášek and Dubinský 1993). The eggs of D. dendriticum are capable of surviving in dry pastures for more than one year (Kas s ai 1999). Fluke eggs may over-winter and remain infective for up to 20 months on pastures (Otranto and Traversa 2002). The highest degree of excretion of eggs was observed by Manga-González et al. (1991) in sheep in the catchment basin of the river Porma in Spain in the winter period, similarly as González-Lanza et al. (1993) in the cattle in the same region in the autumnwinter period. Wintering of the developmental stages is possible in snails and ants (Kas sai 1999). Studies carried out in lowland pastures in the northern part of Germany (S chu ster and Neumann 1988) demonstrated that the degree of infection of snails after the spring peak was decreased in summer and increased again in autumn. The mentioned authors have 
demonstrated that ants containing infectious metacercaria are available for grazing animals particularly in spring at temperatures below $20^{\circ} \mathrm{C}$. That is why most infections of final hosts occur in the period April /May, but low infections are possible during the whole pasture period (Wolf 1976). González-Lanza et al. (1993) remark that the epidemiology of dicrocoeliosis does not depend only on behavioural factors of parasites and the etiology of the hosts, but also on local environmental and ecological factors.

Pathogenesis, immunogenesis, and clinical symptoms

In the first days of infection, when young flukes penetrate into the sites of definitive localization, angioectasis of central veins and portobiliary vessels take place. After the termination of the acute stage, chronic inflammation of the biliary ducts with marked proliferation of the connective tissue develops (Alzieu and Ducos de Lahitte 1991). The lumen of the biliary ducts is extended, their walls are thickened, and the mucosa is proliferated (Kutzer 1997). The walls of the biliary ducts show a picture of glandular hyperplasia, and desquamation of the mucosa is superficial (Rahko 1972). Irrespective of mechanical irritation due to the migration of flukes, pathological changes are attributed to the toxic effect of metabolic products released by parasites (Hillyer and Hopla 1982). Camara et al. (1995) investigated infiltration with inflammatory cells induced by the occurrence of flukes in the bovine liver. They found that an increase in the average number of monocytes and eosinophils corresponds with an increase in the number of flukes. On the other hand, such relationship was not observed in lymphocytes. The od orid is et al. (1999) examined hematological values in sheep infected by $D$. dendriticum. With the exception of increased serum albumin in heavily infected animals (4800-8180 parasites), they did not find statistically significant deviations. Similar conclusions were drawn by Páv and Zajíček (1976) in clinical examinations of the blood of naturally infected moufflons. Small and moderate fluke infections take place subclinically. Serious long-lasting infection (over 5000 trematodes in sheep) causes total induration and cicatrization of the liver with chronic cholangitidis, extension of the biliary ducts, and fibrosis (Kassai 1999). Camara et al. (1996) evaluated the role of the number of parasites in the development of changes induced by flukes in the bovine liver tissue. According to their conclusions, the changes in the surface biliary ducts and lesions of liver cirrhosis were increased with the intensity of infection from 0 to 300 of $D$. dendriticum. With the intensity of infection of 301-600 flukes, they observed a decrease in their further development. Wolf et al. (1984) evaluated the regenerative capability of the ovine liver after the treatment of dicrocoeliosis. In the course of days 20108 after treatment, they did not record unambiguous indices of hepatic regeneration. Sanchez-Campos et al. (1996) have demonstrated that experimental dicrocoeliosis produced an impairment of the capability of the hamster liver to metabolize drugs and xenobiotics. They also studied the effect of experimental dicrocoeliosis on the biliary function of the hamster liver (Sanchez-Campos et al. 1998). Their data suggest that enhancement in choleresis (excretion of bile by the liver cells) had a canalicular origin. In the study of biochemical changes caused by experimentally induced dicrocoeliosis in hamsters, they concluded that dicrocoeliosis resulted in oxidative hepatic damage (Sanchez-Campos 1999; Sanchez-Campos 2000). In humans, Jíra (1998) unequivocally distinguishes the stage of migration through the hepatic parenchyma and subsequent sedimentation in the biliary tract, in the same way as it is known in larger flukes.

With advancing age of animals, fluke infection is increased, often up to several hundred (Jurášek and Dubinský 1993). Dyk and Chroust (1973) observed the lowest findings in one-to four-year moufflons, in five-year-olds the findings were rapidly increased, the highest being in six-year olds. Nahlik et al. (1996) in the study of a moufflon population found that the intensity of dicrocoeliosis infection was higher in the middle-aged group 
(4-7 years) and much higher in moufflon ewes of this group. The age of infected animals might influence the egg output rate, although further investigations are necessary (MangaGonzález et al. 1991). Sex has also been correlated to the sensitivity of definitive hosts to the lancet fluke. The higher rate of in females can be accounted for the fact that dairy heifers and cows graze for several seasons, acquiring infection, while steers and oxen may spend a considerable period of their live in extra natural conditions (Ducommun and Pfister 1991). In the definitive host, the parasites can persist up to 6 years and immunity does not play a role in the regulation and decrease of parasitic population (Kirkwood and Peirce 1971). González-Lanza et al. (2000) concluded that there was no direct relationship between the antibody level and intensity of infection. Although the antibody levels do not correlate with immunological protection of definitive hosts, their detection is important for immunodiagnosis (Otranto and Traversa 2002).

Clinical symptoms are not specific. The disease often takes place inapparently, in particular in older animals. In strong infections (several thousand individuals in sheep), the symptoms are often inexpressive in the form of anaemia, icterus, oedemas, body wasting, and decrease in the production of animals (Jurášek and Dubinský 1993). Most infections of cloven-hoofed game in hunting grounds also take place without any visible symptoms (Rakušan et al. 1998).

\section{Diagnostics}

Intravital diagnostics is carried out with the use of coprological examination methods of concentration of the eggs by means of sedimentation, or flotation. Flotation solutions of high specific density are employed. Rehbein et al. (1999) compared some techniques of counting of the eggs of $D$. dendriticum in faeces. The unambiguously best result was achieved with the use of a $\mathrm{HgI}_{2} / \mathrm{KI}$ flotation solution (specific weight 1.44), whereas with the use of $\mathrm{ZnSO}_{4}$ (specific weight 1.3 and 1.45) and $\mathrm{K}_{2} \mathrm{CO}_{3}$ (specific weight 1.45) flotation solutions markedly worse results were obtained. Sotiraki et al. (1999) examined the effect of stress on the intensity of egg excretion in sheep. They found that stressed animals excreted more eggs. Campo et al. (1999) reported that excretion of the eggs of $D$. dendriticum was higher in the samples of faeces withdrawn in the afternoon than in the samples withdrawn from the same animals in the morning. The number of eggs in one gram of faeces (EPG) correlates in naturally infected ewes with the intensity of infection (Rojo-Vázquez et al., 1981). This correlation was found also in experimentally infected lambs (Campo et al. 1999). B raun et al. (1995) compared findings of fluke eggs in liver, faeces, and bile. They found important differences among them, and the highest sensitivity was documented for bile. Rehbein et al. (2002) tested relationship of faecal egg, gall bladder egg, gall bladder fluke counts and number of $D$. dendriticum in naturally infected lambs and ewes. No correlation was found. Negative coprological finding is not always evidence of parasitological negativity (Campo et al. 1999). In experimentally infected lambs egg excretion started 49-79 days post infection.

Postmortem diagnostics is carried out on the basis of postmortem findings and in slaughterhouse inspection. Thickening and extension of the biliary ducts as well as hepatic induration are the most significant macroscopically observable changes in the liver in dicrocoeliosis. In the thickened biliary ducts there are numerous flukes of various sizes, which are sometimes located also in the gall bladder. When examining the bile sediment from the liver evaluated as suitable for consumption, Klimas et al. (1994) have found that not all cases of dicrocoeliosis can be recognised in the slaughterhouse inspection of meat and that the safety of the inspection is decreased with increasing prevalence of the disease. By comparing coprological results and necropsy of ovine and caprine liver the coprological method proved to detect the presence of dicrocoeliosis out in one out of three infected animals (Jithendran and Bhat 1996). 
Differential diagnostics must differentiate lancet flukes from juvenile stages of a similar size located in the haemorrhagically changed hepatic parenchyma, which is important particularly when acute fasciolosis is suspected (Kassai 1999).

The diagnostic value of serologic tests for the detection of dicrocoeliosis in sheep and goats was estimated by Jithendran et al. (1996). Counter-current immunoelectrophoresis was evaluated as most sensitive. This specific and rapid test of epidemiological examination of sheep and goats makes it possible to diagnose dicrocoeliosis already in the prepatent period. The antibodies are detectable with help of ELISA test, too (Haralabid is 1987; Fi oretti 1980). A high anti-D. dendriticum antibodies titre was detected 4-8 weeks before the appearance of eggs in faeces (A mbrosi et al. 1980). The IgG was detected by ELISA 19 and 23 days earlier than eggs in faeces, too (González-Lanza et al. 2000). ELISA detecting is important for epidemiological studies and early diagnosis of dicrocoeliosis leading to treatment and decreasing of economic losses (Otranto and Traversa 2002).

A useful tool for epidemiological studies of dicrocoeliosis can be the detection of metacercaria of $D$. dendriticum in ants (Heussler et al. 1998).

\section{Treatment}

Treatment is indicated only in severe infections. Due to the localization of flukes in the thinner biliary ducts, a number of antitrematodic agents in recommended doses do not exert sufficient efficacy on $D$. dendriticum and they must be administered repeatedly and in higher doses. Some benzimidazoles and probenzimidazoles are especially recommended, then there are pyrazinoisoquinoline derivatives (praziquantel) or halogenated salicylanilides (closantel) or some other agents (diamfenetide). An overall survey of generalized experience with pharmacotherapy of dicrocoeliosis in sheep is shown in Table 1. More detailed

Table 1

Drugs investigated against lancet fluke (Dicrocoelium dendriticum) in sheep (oral administration)

\begin{tabular}{|c|c|c|l|}
\hline \multirow{2}{*}{ Drug } & $\begin{array}{c}\text { Daily dose } \\
(\mathrm{mg} / \mathrm{kg} \text { body weight })\end{array}$ & $\begin{array}{c}\text { Therapeutic } \\
\text { effect (\%) }\end{array}$ & \multicolumn{1}{|c|}{ Reference } \\
\hline \multirow{2}{*}{ Albendazole } & $1 \times 7,5-10$ & $34-96$ & Theodorides and Freeman (1982), Corba et al. (1988) \\
\cline { 2 - 4 } & $1 \times 15-20$ & $90-100$ & Schuster and Hiepe (1993), Lazic et at. (1994) \\
\cline { 2 - 4 } & $\begin{array}{c}2 \times 7,5 \\
(1-2 \text { week interval) }\end{array}$ & $83-100$ & $\begin{array}{l}\text { Cordero del Campillo et al. (1982) } \\
\text { Lazic et al. (1994) }\end{array}$ \\
\cline { 2 - 4 } & $\begin{array}{c}210 \\
(1 \text { week interval) }\end{array}$ & $90-95$ & $\begin{array}{l}\text { Tharaldsen and Wethe (1980) } \\
\text { Cordero del Campillo et al. (1982) }\end{array}$ \\
\hline Fenbendazole & $1 \times 150$ & 90 & Düwel et al. (1975) \\
\cline { 2 - 4 } & $5 \times 15-25$ & $87-99$ & Düwel et al. (1975), Corba et al. (1981) \\
\cline { 2 - 4 } & $10 \times 5-10$ & $68-97$ & Čorba et al. (1981) \\
\hline Fenbendazole & $1 \times 5-10$ & $89-100$ & Corba et al. (1988) \\
\hline triclabendazole & $1 \times 50-200$ & $66-99$ & Macchioni et al. (1978) \\
\hline Thiabendazole & $1 \times 40-80$ & $74-100$ & Ambrosi and Grelloni (1991) \\
\hline Mebendazole & $1 \times 25$ & 95 & Črba et al. (1978) \\
\hline Cambendazole & $1 \times 7,5-12,5$ & $47-84$ & Kassai et al. (1988), Schusster and Hiepe (1993) \\
\hline Luxabendazole & $1 \times 20$ & $89-99$ & Schuster and Hiepe (1993) \\
\hline Netobimin & $1 \times 50$ & $74-100$ & Onar (1990), Dorchies et al. (1988) \\
\hline Thiofanate & $1 \times 30-50$ & $52-98$ & Güralp et al. (1977), Wolff et al. (1984) \\
\hline Thiofanate + broptianid & $1 \times 50+1 \times 5-6$ & 100 & Tinar et al. (1988) \\
\hline Praziquantel & $1 \times 240-300$ & $70-98$ & Daněk et al. (1987), Calamel et. al (1979) \\
\hline Diamfenetide & & & \\
\hline
\end{tabular}


information is given below in the text in the items concerning the individual active principles. The route of administration is oral (if not stated otherwise).

When studying the efficacy of albendazole in sheep, Lazic et al. (1994) found that a single oral dose of $15 \mathrm{mg} / \mathrm{kg}$, or two doses of $7.5 \mathrm{mg} / \mathrm{kg}$ in a fifteen-day interval showed $100 \%$ efficacy against $D$. dendriticum. Schuster and Hiepe (1993) described more than $90 \%$ efficacy in a dose of 15 and $20 \mathrm{mg} / \mathrm{kg}$. Tharaldsen and Wethe (1980) treated sheep with two doses of 10-12 mg/kg in a one-week interval, which decreased the number of eggs in faeces by approximately $90 \%$. Himonas and Liakos (1980) described the efficacy of albendazole in a dose of 20 and $15 \mathrm{mg} / \mathrm{kg}$ against $D$. dendriticum in sheep (98.2 a 99.6\%). Theodorides and Freeman (1982) demonstrated that albendazole in a dose of $7.5 \mathrm{mg} / \mathrm{kg}$ reduced the number of lancet flukes in sheep by $34.1 \%$, whereas a dose of $20 \mathrm{mg} / \mathrm{kg}$ reduced the number of flukes by $98.6 \%$. Cordero del Campillo et al. (1982) demonstrated that a single dose of $7.5 \mathrm{mg} / \mathrm{kg}$ decreased the parasitic burden by $85.9 \%$, two doses of $7.5 \mathrm{mg} / \mathrm{kg}$ after seven days showed a decrease between 82.4 and $85.5 \%$, whereas two doses of 7.5 $\mathrm{mg} / \mathrm{kg}$ after 14 days decreased the parasitic burden by $91.7 \%$, that a single dose of $10 \mathrm{mg} / \mathrm{kg}$ of albendazole decreased the parasitic burden by $92.2 \%$, and finally that two doses of 10 $\mathrm{mg} / \mathrm{kg}$ in seven-day intervals showed a degree of reduction of parasites of $94.5 \%$. Verification of the efficacy of albendazole was also carried out by Schuster et al. (1989). They found that the intensity of infection was reduced by 72.2 and $87.5 \%$ when administering $7.5 \mathrm{mg} / \mathrm{kg}$ and $10 \mathrm{mg} / \mathrm{kg}$, respectively, and in another experiment they estimated the degrees of efficacy at 92.9 and $94.9 \%$ with the use of 15.0 and $20.0 \mathrm{mg} / \mathrm{kg}$, respectively. Kassai and Fok (1985) achieved $83.4 \%$ efficacy on administering albendazole in a dose of $7.5 \mathrm{mg} / \mathrm{kg}, 83.0-86.3 \%$ efficacy in a dose of $10 \mathrm{mg} / \mathrm{kg}$, and $86.3-$ $100.0 \%$ efficacy in a dose of $15 \mathrm{mg} / \mathrm{kg}$. Čorba et al. (1988) estimated the efficacy of a single-dose administration of $10 \mathrm{mg} / \mathrm{kg}$ at $95.9 \%$. A relatively new alternative of treatment is intraruminal bolus. Boluses have been shown to decrease the excretion of the eggs of D. dendriticum in sheep by o $88.5 \%$ (Č or ba et al. 1991), or by $91.8 \%$ (Č orba et al. 1994). The safety of ovine products and danger of parasite resistance to anthelminthics has to be taken into consideration in case of use of systems based on long-term releasing of drug (Otranto and Traversa 2002).

In sheep infected with $D$. dendriticum, the efficacy of fenbendazole with the use of a single oral of $150 \mathrm{mg} / \mathrm{kg}$ was about $90 \%$, and with the use of five oral doses of $25 \mathrm{mg} / \mathrm{kg}$ the efficacy was about $98 \%$. According to Düwel et al. (1975), the number of administrations of the drug is of greater importance than the total amount of the drug administered. Č orba et al. (1981) found that a ten-day administration of $5 \mathrm{mg} / \mathrm{kg}$ of fenbendazole showed $68.2 \%$ efficacy, whereas an administration of $10 \mathrm{mg} / \mathrm{kg}$ for a period of 10 days showed only $96.8 \%$ efficacy. A five-day administration of 15,20 , and $25 \mathrm{mg} / \mathrm{kg}$ produced $86.7 \%, 95.4 \%$, and 98.9\% efficacy, respectively. Č orba et al. (1988) also estimated the efficacy of a combined preparation of fenbendazole and triclabenbazole in a single dose of $5,7.5$, and $10 \mathrm{mg} / \mathrm{kg}$ at $89.9,89.2$, and $100 \%$, respectively.

The treatment of sheep with a single oral dose luxabendazole of $10.0-12.5 \mathrm{mg} / \mathrm{kg}$ removed 63.2-83.8\% of flukes (Kassai et al. 1988). Also Schuster and Hiepe (1993) reported that in a dose 7.5 and $10 \mathrm{mg} / \mathrm{kg}$ decreased the average number of flukes by only 47 and $59 \%$, respectively.

The efficacy of thiabendazole doses 50,100, and $200 \mathrm{mg} / \mathrm{kg}$ administered in sheep was estimated at 66.0, 80.7, and 98. 8\% (Macchioni et al. 1978).

Ambrosi a Grelloni (1991) described that administrations mebendazole of 40 and 80 $\mathrm{mg} / \mathrm{kg}$ in sheep were effective within a range of $74-85.4 \%$ and $93-99.4 \%$, respectively.

Črba et al. (1978) demonstrated $95.1 \%$ efficacy of a single administration of $25 \mathrm{mg} / \mathrm{kg}$ of cambendazole in sheep. 
A dose of $20 \mathrm{mg} / \mathrm{kg}$ of orally administered netobimin drug induced $98.9 \%$ reduction of parasitic burden in sheep ( $\mathrm{Sanz}$ et al. 1987), a dose of $15 \mathrm{mg} / \mathrm{kg}$ then $91.9 \%$ reduction (Rojo-Vázquez et al. 1989). According to Shuster and Hiepe (1993), a dose of 20 $\mathrm{mg} / \mathrm{kg}$ resulted in $89 \%$ efficacy, and according to Čorba et al. (1993) then in $97.9 \%$ efficacy.

When estimating the anthelminthic efficacy of thiophanate in sheep with a dose of 50 $\mathrm{mg} / \mathrm{kg}, 74.4 \%$ efficacy against $D$. dendriticum was found (Onar 1990). Dorchies et al. (1988) described $99.5 \%, 99.8 \%$, and $100 \%$ efficacy of thiophanate administration at a dose of 50,100 , and $200 \mathrm{mg} / \mathrm{kg}$, respectively, in sheep. The efficacy of $50 \mathrm{mg} / \mathrm{kg}$ of thiophanate in combination with brotianide (halogenated salicylanilide) at a dose of $5-6 \mathrm{mg} / \mathrm{kg}$ was estimated by Tinar et al. (1988) at $99.8 \%$.

The study of Güralp et al. (1977) demonstrated that the therapeutic effect of praziquantel at a dose of 30,40 , and $50 \mathrm{mg} / \mathrm{kg}$ in naturally infected sheep was $52.3,76.2$, and $92.2 \%$, respectively. Similarly as Wolf et al. (1984), they found that single-dose treatment with praziquantel at a dose of $50 \mathrm{mg} / \mathrm{kg}$ resulted in $89-98 \%$ reduction of parasitic burden.

The efficacy of closantel on D. dendriticum is questionable. Čanković et al. (1986) described $54.3 \%$ efficacy with a dose of $5 \mathrm{mg} / \mathrm{kg}$ (i.m.) in sheep, whereas Tin ar et al. (1998) found that an oral dose of $7.5 \mathrm{mg} / \mathrm{kg}$ of fenbendazole $+10 \mathrm{mg} / \mathrm{kg}$ of closantel was not effective on $D$. dendriticum, and a subcutaneous dose of $0.2 \mathrm{mg} / \mathrm{kg}$ of ivermectin $+2 \mathrm{mg} / \mathrm{kg}$ of clorsulon was not effective either.

Oxyklozanide at a dose of $15 \mathrm{mg} / \mathrm{kg}$ was practically ineffective against dicrocoeliosis (Tinar et al. 1988).

Č orba et al. (1978) administered a single dose of $200 \mathrm{mg} / \mathrm{kg}$ of diamfenetide per os to sheep and they estimated its $91.7 \%$ efficacy. A single dose of $240 \mathrm{mg} / \mathrm{kg}$ produced $98 \%$ efficacy of dicrocoeliosis treatment in sheep (Calamel et al. 1979). In the experiments of Daněk et al. (1987), the achieved intensity of effect with a dose of $240-300 \mathrm{mg} / \mathrm{kg}$ ranged from 70.1 to $97.2 \%$.

Prevention

In order to prevent dicrocoeliosis and to limit economic damage, it is recommended to carry out deworming in the winter or early spring period. It considerably limits the dissemination of eggs of $D$. dendriticum in the period of their largest production. It is also important to carry out treatment towards the end of the principal period of infection, which culminates at the turn of April and May (Wolf 1976). Otranto and Traversa (2002) recommend to arrange the treatment two or tree times a year (at the beginning of spring, before housing of animals in late autumn). The control of dicrocoeliosis can be based in limited range on husbandry practices (avoid grazing early in the morning or late in the evening). In order to suppress reinfection of the environment with eggs, treatment would have to be regularly repeated at six-week intervals (the prepatent period is 7-9 weeks). Due to long-term survival of the developmental stages of lancet fluke (their survival is possible in snails and ants), treatment would have to last for a number of years. Because of economic reasons, treatment is practicable only within the framework of an integrated programme, which would be directed against economically more important species of roundworms (Eckert et al. 1992). The effect of lancet flukes on their definitive hosts, nevertheless, should not be underrated. Its unfavourable consequences are connected not only with the financial losses due to the confiscation of the liver in slaughtered farm animals, but also with a negative influence on their efficiency and impairment of the development of young animals (Nesvadba 2000b). Control of snail and ant populations cannot be implemented mainly for ecological reasons. Only in limited areas it is possible to decrease the infection of grazing animals by enclosing the anthills with the branches of trees and bushes in a circle with a distance of $1 \mathrm{~m}$ from the base of the anthill (infected ants are then most frequently 
found 30-50 cm from the base of the anthill) (Eckert and Hertzberg 1994). Effective in infected areas can be breeding of birds (turkeys, ducks, geese, chickens-about 50 birds per ha) due to the control of populations of intermediate hosts (Otranto and Traversa 2002). Vaccination of sheep against dicrocoeliosis was successful in three-month-old lambs. The efficacy of the vaccine was $98 \%$ (Prokopič and Kudrna 1989). The vaccination strategies are not developed at present (Otranto and Traversa 2002).

\section{Infection in humans}

Dicrocoeliosis is a zoonosis. With regard to the mode of infection, people are infected only sporadically. Such a rare case of autochthonous infection was described in former Czechoslovakia in an eleven-year-old boy (Ondriska et al. 1989). Humans can be infected accidentally by swallowing an ant on the vegetation or on various fruits. Children are therefore affected more frequently. Clinical manifestation is usually slight due to accidental infection and on the rule a small amount of parasites. The symptoms include digestive problems, flatulence, vomiting, diarrhoea often combined with constipation, and gall colic. Real infections should be differentiated from false infections, which occur after eating animal tissues infected with flukes. In such case the eggs pass through the digestive tract unchanged as the so-called transit eggs (Jíra 1998).

\section{Dikrocelióza - současný stav poznání se zaměřením na volně žijící druhy zvírat}

Dikrocelióza je v současnosti považována za celosvětově významnou, ale zároveň v běžných chovatelských podmínkách podceňovanou helmintózou domácích a volně žijících přežvýkavců, ale i jiných druhů zvírat a člověka. Práce shromažduje soudobé poznatky o rozšiření, původcích, hostitelích, vývojovém cyklu, epidemiologii, patogenezi, klinických příznacích, diagnostice, léčbě a prevenci parazitózy se zřetelem zejména na volně žijící druhy zvířat. Ačkoli je dikrocelióze celosvětově věnována poměrně značná pozornost, stále existují mnohé velmi podstatné aspekty této trematodózy $\mathrm{k}$ dalšímu ověření. Teprve potom bude možné dikroceliózu v chovech zvírat plně efektivně kontrolovat.

\section{Acknowledgements}

This review was supported by the Grant Agency of Charles University in Prague (Grant No. 96/2002/C/FaF) and Ministry of Education, Youth and Sports (Project No. 313/98:111600002).

\section{References}

ALUNDA, JM , ROJO-VÁZQUEZ, FA 1983: Survival and infectivity of Dicrocoelium dendriticum egss under field conditions in nw Spain. Vet Parasitol 13: 245-249

ALUNDA, JM, ROJO-VÁZQUEZ, FA 1984: Effect of some abiotic factors on the survival of Dicrocoelium dendriticum egss in laboratory conditions. Folia Parasit 31: 121-126

ALZIEU, JP, DUCOS DE LAHITTE, J 1991: Bulletin des G.T. V. In: SÁNCHEZ-CAMPOS, S., TUAÓN, M. J. GONZÁLEZ, P., MARÍN, J. J. G., GONZÁLEZ-GALLEGO, J. 1998: Enhanced bile formation induced by experimental dicrocoeliosis in the hamster. Life Sci 63: 1963-1974

AMBROSI, M, BALDELLI, B, PIERGILI FIORETTI, D, POLIDORI, GA, GIRELLONI, V, MORETTI, A, PRINCIPATO, M 1980: Dicroceliosis ovina: insorgenza e decorso della infezione da Dicrocoelium dendriticum studiati noc metodi parassitologici e sierologici (ELISA) in quattro gruppi di ovini di tracia. Rivista di Parassitologia. In: OTRANTO, D., TRAVERSA, D. 2002: A review of dicrocoeliosis of ruminants including recent advances in the diagnosis and treatment. Vet Parasitol 107: 317-335

AMBROSI, M, GRELLONI, V 1991: Use of mebendazole on the field against gastrointestinal, hepatic and respiratory helmints in sheep. Documenti Veterinari 12: 89-91

ANDRAS, T 1995: Helminth infection of moufflon (Ovis-ammon-musimon) in the Zemplen mountains (Hungary). Magy Allatorv Lapja 50: 166-168

ANSARI, MZ, RAI, MK, CHAUHAN, HVS 1989: Pathology of liver, lung and caecum of yak (Bos poephagus) infected with Dicrocoelium, Fasciola, Echinococcus and Trichuris. Indian J Anim Sci 59: 552-554 
ASPÖCK, H, AUER, H, PICHER, O 1999: Parasites and parasitic diseases in prehistoric human populations in Central Europe. Helminthologia 36: 139-145

BADIE, A 1978: Ovine dicrocoeliasis: incidence of climatic factors and share in setting of forecasting method. Ann Parasitol Hum Comp 53: 373-385

BORAY, JC 1985: Flukes of domestic animals. In: ECKERT, J., HERTZBERG, H. 1994: Parasite control in transhumant situations. Vet. Parasitol. 54: 103-125

BRAUN, U.,WOLFENSBERGER, R., HERTZBERG, H. 1995: Diagnosis of liver flukes in cows - a comparison of the findings in the liver, in the feces, and in the bile. Schweiz Arch Teirheilkde 137: 438-444

CALAMEL, M, VILLEMIN, P, LEIMBACHER, F 1979: The effectiveness of Diamphenethide in the treatment of ovine Dicrocoeliosis. Rec Méd vét 155: 37-46

CAMARA, L, PFISTER, K, AESCHLIMANN, A 1995: Infiltration of inflammatory cells in the portal lobular due the presence of Dicrocoelium dendriticum in the bovine liver. Revue Méd Vét 146: 631-636

CAMARA, L, PFISTER, K, AESCHLIMANN, A 1996: Histopatological analysis of bovine livers infected by Dicrocoelium dendriticum. Vet Res 27: 87-92

CAMPO, R, MANGA-GONZÁLEZ, MY, GONZÁLEZ-LANZA, C 1999: Relationship between egg output and parasitic burden in lambs experimentally infected with different doses of Dicrocoelium dendriticum (Digenea). Vet Parasitol 87: 139-149

CIBEREJ, J, LETKOVA, V, KACUR, M 1997: Helminth fauna of chamois (Rupicapra rupicapra) in the Slovakia Raj National Park area. Slovenský Veterinársky Časopis 22: 301-302

CORDERO DEL CAMPILLO, M, ROJO VÁZQUEZ, FA, DIEZ BAÑOZ, P, CHATON-SCHAFFNER, M 1982: Albendazole efficiency against a natural Dicrocoelium dendriticum infestation in sheep. Revue Méd Vét 133: 41-49

CRINGOLI, G, RINALDI, L, VENEZIANO, V, CAPELLI, G, MALONE, JB 2002: A cross-sectional coprological survey of liver flukes in cattle and sheep from an area of the southern Italian Apennines. Vet Parasitol 108: 137-143

ČANKOVIĆ, M, ROZMAN, M, IMAMOVIĆ, V, PAVICA, E 1986: Examination of the eficacy of action of Fascoverma (Klozantel) on Fasciola hepatica and Dicrocoelium dendriticum in ewes and the body mass of lambs at birth and weaning. Vet Glasnik 40: 337-342

ČORBA, J, ANDRAŠKO, H, ŠTOFFA, P, LEGÉNY, J, KRUPICER, I, HAŽLINSKY, M 1978: Efektivnost Cambendazolu (Bolan pasta) u oviec invadovaných trematódmi Dicrocoelium dendriticum Vet Med-Czech 23: 485-489

ČORBA, J, HOVORKA, J, ŠPALDONOVÁ, R 1988: Efficacy of combined fenbendazole/triclabendazole preparation against helminths in sheep and cattle. Helminthologia 25: 157-163

ČORBA, J, KRUPICER, I, LEGÉNY, J, JURIS, P, VESELY, L 1991: Effect of a controlled-release albendazole capsule on parasitism and productivity of sheep. Vet Parasitol 40: 273-279

ČORBA, J, KRUPICER, I, LEGÉNY, J, ŠTOFFA, P 1988: Aldifal-nové širokospektrálne anthelmintikum pre prežúvavce. Veterinářství 38: 121-122

ČORBA, J, KRUPICER, I, PEŤKO, B, VÁRADY, M 1993: Efficacy of netobimin against liver flukes, gastrointestinal and lungworms in naturaly infected sheep. Helminthologia 30: 57-61

ČORBA, J, KRUPICER, I, VARADY, M, PETKKO, B 1994: Účinnosti intraruminálnych albendazolových bólusov na gastrointestinálne nematódy a trematódy Dicrocoelium dendriticum u oviec. Vet Med-Czech 39: 297-304

ČORBA, J, ŠTOFFA, P, LEGÉNY, J, KRUPICER, I 1981: Efektívnost fenbendazolu (Panacur) na najdôležitějšie trematódy a cestódy prežúvavcov. Veterinářství 31: 118-121

DANĚK, J, BABÍČEK, K, ROUTA, V, PAULOVÁ, J 1987: Coryphamin susp. (Spofa) př́pravek s obsahem diamfenetidu k léčbě dikroceliózy a fasciolózy u ovcí a krav. Veterinářství 37: 117-119

DEMIR, S, TINAR, R, KAPLAN, A 1995: Helminths obtained from a donkey. Türkiye Parazitoloji Dergisi 19: $119-123$

DORCHIES, Ph, DUCOS DE LAHITTE, J, ALZIEU, JP, BICHET, H 1988: Treatment test of sheep dicrocoeliasis by the thiophanate. Revue Méd Vét 139: 277-279

DUCOMMUN, D, PFISTER, K 1991: Prevalence and distribution of Dicrocoelium dendriticum and Fasciola hepatica infections in cattle in Switzerland. Parasitol Res 77: 364-366

DÜWEL, D, KIRSCH, R, REISENLEITER, R, 1975: The efficacy of fenbendazole in the control of trematodes and cestodes. Vet Rec 97: 371

DYK, V, CHROUST, K 1973: Helminths and coccidia in moufflons the School Forest District Křtiny near Blansko. Acta Vet Brno 42: 159-173

ECKERT, J, HERTZBERG, H 1994: Parasite control in transhuman situations. Vet Parasitol 54: 103-125

ECKERT, J, KUTZER, E, ROMMEL, M, BÜRGER, HJ, KÖRTING, W 1992: Veterinärmedizinische Parasitologie. Verlag Paul Parey, Berlin, Hamburg, p. 905

FERRE, I, ORTEGAMORA, LM, ROJO-VÁZQUEZ, FA 1994: Prevalence of Dicrocoelium dendriticum infection in sheep in Leon Province (NW Spain). Prev Vet Med 21: 147-154

FILO, Š, KRUPICER, I, JURIŠ, P, FETISOV, V 1986: Frekvencia výskytu helmintov oviec chovaných v nových technológiách v podhorskej oblasti SSR. Veterinářství 36: 88-86

FIORETTI, DP, BALDELLI, B, AMBROSI, M, POLIDORI, GA, MORETTI, A 1980: The ELISA used in the study of antibodies in sheep infected with Dicrocoelium dendriticum. Rivista di Parassitologia 41: 289-292 
GALLEGO, J 1998: Enhanced bile formation induced by experimental dicrocoeliosis in the hamster. Life Sci 63: 1963-1974

GARGILI, A, TUZER, E, GULANBER, A, TOPARLAK, M, EFIL, I, KELES,V, ULUTAS, M 1999: Prevalence of liver fluke infections in slaughtered animal in Trakya (Thrace), Turkey. Turk J Vet Anim Sci 23: 115-116

GEBAUER, O, HOHORST, W 1968: Beitrag zur Epidemiologie des Lanzettegelbefalles unter alpinen Mittelgebirgsverhältnissen. In: ECKERT, J., HERTZBERG, H. 1994: Parasite control in transhumant situations. Vet Parasitol 54: 103-125

GONZÁLEZ-LANZA, C, MANGA-GONZÁLEZ, MY, CAMPO, R, DEL-POZO, MP 1997: Larval development of Dicrocoelium dendriticum in Cernuella (Xeromagna) cespitum arigonis under controlled laboratory conditions. J Helminthol 74: 311-317

GONZÁLEZ-LANZA, C, MANGA-GONZÁLEZ, MY, CAMPO, R, DEL-POZO, P, SANDOVAL, H, OLEAGA, A, RAMAJO, V 2000: IgG antibody response to ES or somatic antigens of Dicrocoelium dendriticum (Trematoda) in experimentally infected sheep. Parasitol Res 86: $472-479$

GONZÁLEZ-LANZA, C, MANGA-GONZÁLEZ, MY, DEL-POZO-CARNERO, P 1993: Coprological study of the Dicrocoelium dendriticum (Digenea) egg elimination by cattle in highland areas in Leon Province, Northwest Spain Parasitol Res 79: 488-491

GÜRALP, N, O?UZ, T, ZEYBEK, H 1977: Chemotherapeutic trials with Embay 8440® (Praziquantel, Droncit) against Dicrocoelium dendriticum in naturally infected shepp. Ankara UniversitesiVeteriner Fakultesi Dergisi 24: $85-89$

HARALABIDIS, STH 1987: Seroepidemiology of parasitic diseases of sheep and goats by means of ELISA. Bulletin of the Hellenic Veterinary Medical Society 38: 215-223

HEUSSLER, V, KAUFMANN, H, GLASER, I, DUCOMMUN, D, MULLER, C, DOBBELAERE, D 1998: A DNA probe for the detection of Dicrocoelium dendriticum in ants of Formica spp. and Lasius spp. Parasitol Res 84: 505-508

HIEPE, T 1994: Helminth control in sheep and goat flocks. Tierarztl Prax 22: 29-34

HILLYER, GV, HOPLA, CE 1982: Handbook Series in Zoonoses. In: SÁNCHEZ-CAMPOS, S., TUĄÓN, M. J., GONZÁLEZ, P., MARÍN, J. J. G., GONZÁLEZ-GALLEGO, J. 1998: Enhanced bile formation induced by experimental dicrocoeliosis in the hamster. Life Sci 63: 1963-1974

HIMONAS, CA, LIAKOS, V 1980: Efficacy of albendazole against Dicrocoelium dendriticum in sheep. Vet Rec 107: $288-289$

CHARTIER, C, RECHE, B 1992: Gastrointestinal helminths and lungworms of French dairy goats prevalence and geographical distribution in Poitou-Charentes. Vet Res Commun 16: 327-335

CHROUST, K 2001: Parazitární choroby spárkaté zvěře. RNDr. Ivan Straka, Újezd u Brna, p. 52

JÍRA, J 1998: Lékařská helmintologie - Helmintoparazitární nemoci. Galén, Praha, p. 495

JITHENDRAN, KP, BHAT, TK 1996: Prevalence of Dicrocoeliosis in sheep and goats in Himachal Pradesh, India. Vet Parasitol 61: 265-271

JITHENDRAN, KP, VAID, J, KRISHNA, L 1996: Comparative evaluation of agar gel precipitation, counterimmunoelectrophoresis and passive haemagglutination test for the diagnosis of Dicrocoelium dendriticum infection in sheep and goats. Vet Parasitol 61: 151-156

JURÁŠEK, V, DUBINSKY, P 1993: Veterinárna parazitológia. Príroda, Bratislava, p. 382

KASSAI, T 1999: Veterinary Helminthology. Butterworth Heinemann, Oxford, p. 260

KASSAI, T, BEKESI, L 1993: Survey on the prevalence of animal parasitoses in Hungary. Magy Allatorv Lapja 48: 721-730

KASSAI, T, FOK, E 1985: Field observations on the albendazol-therapy of ovine fasciolosis and dikroceliosis. Magy Allatorv Lapja 40: 445-458

KASSAI, T, TAKÁTS, C, FOK, E, REDL, P 1988: Activity of luxabendazole against liver flukes, gastrointestinal roundworms, and lungworms in naturally infected sheep. Parasitol Res 75: 14-18

KIRKWOOD, AC, PEIRCE, MA 1971: The longevity of Dicrocoelium dendriticum in sheep. Res Vet Sci 12: 588-589

KLIMAS, M, SCHUSTER, R, HIRSCHMANN, RU 1994: Vorkommen und Verbreitung von Dicrocoelium dendriticum in Nord-West-Thüringen. Mh Vet-Med 49: 317-322.

KÖNIG, M, GOTTSTEIN, B 1997: Nachweishäufigkeut ausgewählter Parasiten beim Rind, Schaf und Schwein im Schlachthof. In: NESVADBA, J. 2000: Dva př́ípady dikroceliózy u koček. Veterinářství 11: 471-472

KOTRLÁ, B, ČERNY, V, KOTRLY, A, MINÁŘ, J, RYŠAVY, B, ŠEBEK, Z 1984: Parazitózy zvěře. Academia, Praha, p. 192

KUTZER, E 1997: Helminths and Helminthic Diseases of Wild Animals in Europe. Instit f Parasitol und Zool der Veterinärmed Univ Wien, Wien, p. 33

LAVIN, S, MARCO, I, VILAFRANCA, M, FELIU, C, VIŇAS, L 1998: Dicrocoelium dendriticum infestacion of moufflons (Ovis musimon) in Catalonia. Vet Rec 143: 396

LAZIC, S, LALIC, M, PAVLOVIC, R, MARKOVIC, R, NIKOLIC, V, AVAKUMOVIC, D, MANDIC, L 1994: Studies on the efficacy of albendazole (ICN Galenika) in the treatment of the major helminthoses of sheep. VetGlasnik 48: 511-516

LIETAVA, P 1984: Dikrocelióza v spádové oblasti štátného veterinárného ústavu vo Zvolene. Veterinářství 34: 448-449 
LOCHMAN, J, KOTRLY, A, HROMAS, J 1979: Dutorohá zvěř. Státní Zemědělské Nakladatelství, Praha, p. 384 MACCHIONI, G, MARCONCINI, A, TASSI, P, VIDENHORN, O 1978: Efficacy of tiabendazole treatment of sheep for Dicrocoelium dendriticum infection. Clinica Veterinaria 101: 185-190

MACKO, JK, ŠTEFANČÍKOVÁ, A 1996: A peculiar finding of trematodes of the genus Dicrocoelium (Dicrocoelidae, Trematoda) from Turdus pilaris L. (Passeriformes) in Slovakia. Helminthologia 33: 31-35

MANGA-GONZÁLEZ, MY 1992: Some land mollusc species involved in the life cycle of Dicrocoelium dendriticum (Trematoda) in the wild in the province of Leon (NV Spain). In: ECKERT, J., HERTZBERG, H. 1994: Parasite control in transhumant situations. Vet Parasitol 54: 103-125

MANGA-GONZÁLEZ, MY, GONZÁLEZ-LANZA, C, DEL-POZO-CARNERO, P 1991: Dynamics of elimination of Dicrocoelium dendriticum (Trematoda, Digenea) eggs in the faeces of lambs and ewes in the Porma basin (León, NW Spain). Ann Parasitol Hum et Comp 66: 57-61

MEIER, T 1987: Die Landschnecken im Alpstein und seiner Umgebung. In: ECKERT, J., HERTZBERG, H. 1994: Parasite control in transhumant situations. Vet Parasitol 54: 103-125

NAHLIK, A, TAKACS, A, BOTEV, N 1996: Analysis of some density-dependent factors in two moufflon populations. Proceedings International Union of Game Biologists 22nd congress Sofia, Bulgaria, 4-8 September 1995, pp. 250-255

NAKAMURA, T, NAKAHARI, J, MACHIDA, N, KIRYU, K, MACHIDA, M 1984: Dicrocoeliasis in the wild Japanese serow (Capricornis crispus). Jpn J Vet Sci 46: 405-408

NESVADBA, J 2000a: Two cases of feline dicrocoeliasis. Veterinářství 50: 471-472

NESVADBA, J 2000b : Personal communication.

ODENING, K 1969: Der Lanzetteegel oder Kleine Leberegel (Dicrocoelium dendriticum). In: ECKERT, J., HERTZBERG, H. 1994: Parasite control in transhumant situations. Vet Parasitol 54: 103-125

ONAR, E 1990: Efficacy of thiophanate and albendazole against natural infections Dicrocoelium dendriticum, Fasciola hepatica and gastrointestinal nematodes and cestodes in shepp. Vet Parasitol 35: 139-145

ONDRISKA, F, SOBOTA, K, JANOSEK, J, JOKLOVÁ, E 1989: A rare case of human autochthonus dicrocoeliasis in Czechoslovakia. Bratislavské Lek Listy 90: 467-469

OTRANTO, D, TRAVERSA, D 2002: A review of dicrocoeliosis of ruminants including recent advances in the diagnosis and treatment. Vet Parasitol 107: 317-335

PÁV, J, KOŽUŠNÍK, Z, MATOUŠEK, Z, VANČURA, V, ZAJÍČEK, D 1981: Choroby lovné zvěře. Státní Zemědělské Nakladatelství, Praha, p. 272

PÁV, J, ZAJÍČEK, D 1976: Hodnoty klinického vyšetření krve spárkaté zvěře ve vztahu k přirozeným polyvalentním invazím cizopasníků. Práce VÚLHM, 48: 5-30

PROKOPIČ, J, KUDRNA, K, 1989: Vaccination of sheep against Dicrocoelium dendriticum. Magy Állatorv Lapja 44: $405-406$

RAHKO, T 1972: Studies on the pathology of dicrocoeliasis and fascioliasis in the goat. Acta Vet Scand 13: 554-562

RAKUŠAN, C, BROŽ, V, HROMAS, J, HUSÁK, F, KOHOUTEK, J, LOCHMAN, J, MACOUREK, J, PÁV, J 1988: Základy myslivosti. Státní Zemědělské Nakladatelství, Praha, 416 p.

REHBEIN, S, LINDNER, T, KOKOTT, S 2002: Dicrocoelium dendriticum infection in sheep: faecal egg count, gall bladder egg count, gall bladder fluke count, total fluke count. Helminthologia 39: 71-75

REHBEIN, S, VISSER, M, WINTER, R 1998: Endoparasites of sheep from the Swabian Alb. Dtsch Tierärztl Wschr 105: 397-436

REHBEIN, S, KOKOTT, S, LINDNER, T 1999: Evaluation of techniques for the enumeration of Dicrocoelium eggs in sheep faeces. J Vet Med 46: 133-139

ROJO-VÁZQUEZ, FA, CORDERO DEL CAMPILLO, M, DIEZ-BAÑOS, P, CHATON-SCHAFNER, M 1981: Relationship existing between the number of eggs in the feces and parasitic charge during ovine natural Dicrocoelium dendriticum infestation. Revue Méd Vét 132: 601-607

ROJO-VÁZQUEZ, FA, MEANA, A, TARAZONA, JM, DUNCAN, JL 1989: The efficacy of netobimin, 15 $\mathrm{mg} / \mathrm{kg}$, against Dicrocoelium dendriticum in sheep. Vet Rec 124: 512-513

SANCHEZ-CAMPOS, S, GONZÁLEZ, P, FERRERAS, M GARCIA-IGLESIAS, MJ, GONZÁLEZ-GALLEGO, J, TUNON, MJ 2000: Morphologic and biochemical changes caused by experimentally induced dicrocoeliosis in hamsters (Mesocricetus auratus). Comp Med 50: 147-152

SANCHEZ-CAMPOS, S, TUNON, MJ, GONZÁLEZ, P, CAMPO, R, FERRERAS, MC, MANGA, Y, GONZÁLEZ-GALLEGO, J 1996: Effects of experimental dicrocoeliosis on oxidative drug metabolism in hamster liver. Comp Biochem Physiol C-Pharmacol Toxicol Endocrinol 115: 55-60

SANCHEZ-CAMPOS, S, TUNON, MJ, GONZÁLEZ, P, GONZÁLEZ-GALLEGO, J 1999: Oxidative stress and changes in liver antioxidant enzymes induced by experimental dicrocoeliosis in hamsters. Parasitol Res 85: 468-474

SANCHEZ-CAMPOS, S, TUNON, MJ, GONZÁLEZ, P, MARIN, JJG, GONZÁLEZ-GALLEGO, J 1998: Enhanced bile formation induced by experimental dicrocoeliosis in the hamster. Life Sci 63: 1963-1974

SANZ, F, TARAZONA, JM, JURADO, R, FRIAS, J, TARAZONA, JV, DUNCAN, JL 1987: An evaluation of the efficacy of netobimin against Dicrocoelium dendriticum in sheep. Vet Rec 120: 57-58

SCHUSTER, R 1991: Factors influencing the metacerkarial intensity in ants and the size of Dicrocoelium dendriticum metacerkarial cysts. J Helminthol 65: 275-279 
SCHUSTER, R 1992: The modification of Helicella obvia by Dicrocoelium parthenitae. Angew Parasitol 33 : 61-64

SCHUSTER, R 1993: Infection patterns in the first intermediate host of Dicrocoelium dendriticum. Vet Parasitol 47: 235-243

SCHUSTER, R, HIEPE, T 1993: The treatment of dicrocoeliosis in sheep. Mh Vet-Med 48: 657-661

SCHUSTER, R, MEINEL, L, HIRSCHMANN, RU 1991: Zur Verbreitung der Dicrocoeliose im Land Brandenburg. Mh Vet-Med 46: 743-746

SCHUSTER, R, NEUMANN, B 1988: Seasonal occurrence of Dicrocoelium dendriticum in intermediate hosts. Angew Parasitol 29: 31-36

SCHUSTER, R, RUSCHER, HJ, MEWES, G 1989: Studies into effectiveness of Vermitan® (Albendazole) on Dicrocoelium dendriticum in sheep. Mh Vet-Med 44: 457-458

SOTIRAKI, ST, LEONTIDES, LS, HIMONAS, CA 1999: The effect of transportation and confinement stress on egg production by Dicrocoelium dendriticum in sheep. J Helminthol 73: 337-339

SOVERI, T, VALTONEN, M 1983: Endoparasites of hares (Lepus timidus and L. europaeus) in Finland. J Wildlife Dis 19: $337-341$

SPINDLER, EM, ZAHLER, M, LOOS-FRANK, B 1986: Behavioural aspects of ants as second intermediate host of Dicrocoelium dendriticum. Z Paresitenkd 72: 689-692

STUHRBERG, E, NICKEL, S, HIEPE, T 1975: Dicrocoelium dendriticum beim Schaf im DDR-Bezirk Frankfurt/Oder. Angew Parasitol 16: 129-135

TAKACS, A 2000: Data on the parasitological status of fallow deer population living in a free hunting area. Magy Allatorv Lapja 122: 618-620

THARALDSEN, J, WETHE, JA 1980: A field trial with albendazole against (Dicrocoelium lanceolatum) sheep. Nord Vet Med 32: 308-312

THEODORIDES, VJ, FREEMAN, JF 1982: Anthelmintic activity of albendazole against Dicrocoelium dendriticum in sheep. Vet Med 77: 569-570

THEODORIDIS, Y, SOTIRAKI, S, PAPADOPOULOS, E 1999: Observations on blood figure of sheep infected with Dicrocoelium dendriticum. Bulletin of the Hellenic Veterinary Medical Society 50: 300-304

TINAR, B, DOGAN, H, DEMIR, S, AKOYOL, CV 1988: Treatment of Dicrocoelium dendriticum with a combination of thiophanate and brotianide. Vet Rec 123: 650-651

TINAR, R, COSKUN, S, AKYOL, V, SENLIK, B 1998: Efficacy of some novel anthelmintic combinations against helminths of sheep. Acta Parasitol Turc 22: 96-100

VRZGULA, L, JAGOŠ, P, BARTKO, P, BOUDA, J, CHYLA, M, ILLEK, J, KOVÁČ, G 1986: Vnútorné choroby prežúvavcov a ošípaných. Príroda, Bratislava, p. 281

WOLFF, K, 1976: Zur Epizootologie der Dicrocoeliose des Schafes. In: ECKERT, J., HERTZBERG, H. 1994: Parasite control in transhumant situations. Vet Parasitol 54: 103-125

WOLFF, K, HAUSER, B, WILD, P 1984: Dicrocoeliosis of sheep: Investigation of the pathogenesis and regeneration of the liver after therapy. Berl Münch Tierärztl Wschr 97: 378-387 